\title{
Approaches to Travel Writing in Isabella L. Bird's The Golden Chersonese and the Way Thither
}

\author{
Nurhanis Sahiddan \\ College of Foundation and General Studies, Universiti Tenaga Nasional (UNITEN) \\ Jalan IKRAM-UNITEN, 43000 Kajang, Selangor, Malaysia \\ Tel: 60378630227 E-mail: nurhanis168@gmail.com
}

Received: 16-05- 2012

doi:10.7575/ijalel.v.1n.2p.163
Accepted: 20-06- 2012

Published: 01-07- 2012

\begin{abstract}
This paper examines the approaches to travel writing in Isabella L. Bird's The Golden Chersonese and the Way Thither. There are various approaches adapted by travel writers, such as nature, ideas on home, notions of space, ethnography and others. This paper studies the historical factors as well as the cultural or ethnographical factors evident in The Golden Chersonese and the Way Thither. Extracts and instances in the travel writing shall be explicated to strengthen the view on the approaches in the work. The two main approaches in travel writing that shall be explained in the light of the literature are the notion of space, or discovering of places not known to the European world and representing the ethnography of the Malay Peninsula.
\end{abstract}

Keywords: Travel writing, Nature in the Malayan Peninsula, Representation of Places, Ethnography

\section{Approaches in Travel Writing}

In order to understand some of the main ideas in travel literature, the genre for The Golden Chersonese and the Way Thither by Isabella L. Bird, this study will first look at the relationship between literature and tourism (Robinson \& Andersen, 2002, p. 3). There is an issue of space which shall be further discussed throughout the paper. According to Robinson and Andersen, a focus in cultural geography results from the relationship between literature and physical space, in a way, literature is able to reflect real space and its functions (2002, p. 3). Furthermore, Robinson and Andersen define the notion of 'space in literature', where writers define and redefine spaces using their work (p. 3). In other words, space is fictionalised by its literary expression. In distinguishing between a creative writing and travel literature, the guide book is 'not sustained by a narrative exploiting the devices of fiction'. The primary function of guide books is for information transfer and to define the touristic experience, according to Robinson and Andersen. Also according to them, the travel book, made through the creative writing process draws freely upon literary motifs and the subjectivity of autobiographical accounts of travel (p. 10). Travel writing is in a way, pseudoethnographic, displaying an objective reporting in a personal account. Therefore, to Robinson and Andersen, travel books may sometimes include elements of storytelling approaches, fiction techniques, literary embellishments and elongating the truth which shows that they are edging into the field of literature (p. 10).

Another discussion point in filling the blank spaces through travel and travel writing is that tourists do not recognize administrative boundaries. They pass, often unconsciously, from district to district, county to county and state to state. Over the years, territories explored have been marked out without the relation to administrative or political convenience, rather through the reference made by writers and their works (Robinson \& Andersen, 2002, p. 20).

Throughout the paper, we shall also see the connection between travel writing and history as can be seen in Isabella L. Bird's The Golden Chersonese and the Way Thither. This paper will also explicate some of the ways Bird mentions the nature of the Malayan Peninsula as well as its significance in the country in the Victorian era or the 1880s. Other than that, this paper shall also look at how Bird represents the ethnography of the places she visited in her travel writing according to some of the theories in postcolonialism. According to Robinson and Andersen (2002), travel writings act as records to historical accounts on the evolution of travel and tourism patterns and the cultural contexts where they are drawn upon (p. 10). Furthermore, according to Robinson and Andersen, studies of the eighteenth and nineteenth century have examined various discourses and writings of

Page | 163 
International Journal of Applied Linguistics \& English Literature

ISSN 2200-3592 (Print), ISSN 2200-3452 (Online)

Vol. 1 No. 2; July 2012

travel as 'gateways of understanding' to geographies of cultural difference, colonialism or imperialism, feminism, romanticism and aesthetics which are present in Bird's work. For example, the notion of self and 'Other' which can be seen in Bird's work relates to the post colonialism theory of literature. According to Barry (2002), children, both black and white, will be taught to view history, culture and progress as marked by the arrival of the Europeans (p. 193). The colonisers or the Europeans somehow play a part in discovering the places and bring about the notion of indifference. Since Bird is a writer representing the Occident, the representation of difference in her work is not exactly the reflection of the ethnic or cultural values being described in terms of the fixed notion of tradition (Bhabha, 1994, p. 2). The disadvantages of the western representation of the notion of difference in discourse are due to the process where forms of racial, cultural or historical otherness are disregarded according to the postcolonial theory of literature (Bhabha, 1994, p. 67). However, it shall be seen further in this study that Bird romanticises the description of the culture of the Other in her work, focusing on the beauty and rich tradition of the Malay Peninsula and some of the other Asian countries she visited.

\subsection{Tourism, Landscape and Spaces}

The writer's home plays a part in tourism resource with appeal across a range of markets. They are represented by the houses, apartments and rooms that have born witness to various stages of the author's life from birth until death (Robinson \& Andersen, 2002, p. 15). According to Robinson and Andersen, the writers' home provide tangible connections between the creator and the created, allowing the reader to experience the emotional accounts and activities (p. 15). The writer's home provides an emotional experience which highly influences their writings and how they view other spaces in their travels. Representations of the people other than the west or the analysis of the Orient is an entailment of such writings on the author's accounts on his or her travels (Crossley, 2005, p. 200). It shall be seen in the discussion how Bird represent the Orient in her travel writing and her own emotional accounts in its process. This can be seen from how Bird romanticise the people and places from her visits by describing in detail entailing her own fascination towards the culture and ethnography. Thus, the symbol of the writer's home becomes a series of settings for the reader's emotional engagement with the writer and his or her work. Also according to Robinson and Andersen, this emotional bond between the writer and their homes makes it possible for ordinary rooms to be transformed into staged backdrops for the purpose of recollection and imagination (p.17). Furthermore, according to them, the preserved home of the deceased author would create the idea that the author might re-enter the home at any time (p. 19). Somehow our imagination creates an illusion that the writer is real as are their books.

When discussing literature as heritage or historical accounts and record, Robinson and Andersen (2002) mentioned that literature possesses public legacy which is expressed in emotional and spatial terms, enabling us to talk of literary heritage (p. 26). In other words, history and culture could be represented in literature. This can be seen in Bird's The Golden Chersonese and the Way Thither where Bird makes various accounts of the Malayan culture and heritage during her travel to the Golden peninsula. Also according to them, literary age may change, but we can always turn to a collective and cumulative past in published works, their performance and interpretation (p. 26). Literatures act as historical record and provide different views in one's culture and heritage. In The Golden Chersonese and the Way Thither, the culture of the Malayan Peninsula and other Asian countries Bird travelled to are viewed through the European gaze and not through the view of the colonised. Therefore, we understand the terms and names of places in works such as Shakespeare's, Wordsworth's and Hardy's not only in geographical terms, but also as passages of time.

Travel literature and landscape or nature are almost inseparable as writers draw upon the landscape and picturesque nature of a place an adapting them into their works. Various sites and locations associated with writers and their literature are part of a wider perceptual experience with focus on the aesthetic (Robinson \& Andersen, 2002, p. 29). According to the same authors, in British literary tourism, landscapes of scenic beauty and picturesque spaces have become prominent features in travel literature. There is a prominent sense of dramatic 'wilderness' in British travel literature (p. 29). In accordance to that, travel literature entangles with the concepts of beauty and nostalgia in real and imagined landscapes (p. 29).

Another feature of most travel writings is the romanticising of nature, where the nature of the place explored is described with great emphasis and elaboration. According to Robinson and Andersen (2002), the romantic literature in creating tourism of the picturesque is well-documented in Western Europe (p. 29). They added, romanticising the landscape involves overly-descriptive accounts of places and events when even the most unappealing of places and events can be enlivened when romanticised (Robinson, 2002, p. 45). Bird's writing adheres to this notion as she romanticises the people of the Malay Peninsula such as the Klings where she describes them as attractive and rich in tradition (Bird, 1883, p. 117). Robinson and Andersen (2002) also Page | 164 
International Journal of Applied Linguistics \& English Literature

ISSN 2200-3592 (Print), ISSN 2200-3452 (Online)

Vol. 1 No. 2; July 2012

claimed that the most important point of creative literature is usually not to offer accurate representations of places (p. 49). Since travel writing is a form of creative writing, it is not so strange that non-accurate representations of places are evident in them. The author does not commonly uses place as material reality, but more as imaginative space. From the travel writing being studied, it can be seen that places of the writer's visits are romanticised, giving a look into her imagination and internal feelings toward the ethnography of the people in the peninsula. Another notion is that fantastic places provide inspiration and themes for developing tourism, trails and activities and encounters with some fantastic place may stimulate an impulse to search for the original sources of the notions (p. 51). This can be seen in how Bird describes the beauty of the landscape in the Malay Peninsula as well as the culture of the people's interrelation to nature.

There are two techniques in describing a place of travel which are analysed in this paper. The first is with disguised nature of the place and the second, depicting the place in reality. By inventing and disguising places, the authenticity in the tourist experience presents 'objectivity' measured scientifically against evidence, thus portraying the role of a historian (Robinson, 2002, p. 52). In the same article, literature interrelates with disguised places, where some are more hidden in their description in fiction (p. 53).

On writings and readings of 'real' places and spaces, the foundation of the text is the writer's own experience of the places. This can be reflective and reflexive of the relationship that the writer has with the place of travel (Robinson, 2002, p. 54). This method of depicting places in reality can be seen in Bird's writing. In The Golden Chersonese and the Way Thither, Isabella Bird emits a more positive image of Malaysia and Singapore or the Malay Peninsula in the eighteenth century and chooses to describe things in detail. She somehow does not disguise anything in the peninsula and depicts the cultures, nature and people in reality, how she sees them. Bird's works rely on her personal experiences. They are her own accounts of the travel where she experiences the travel and adventure first-hand, venturing in a world beyond her home.

The Grand Tour in the eighteenth century aims for education and culture on the quest for health and pleasure (Towner, 2002, p. 227). It is a practice of visiting the major cultural centres of Europe, particularly those of Italy and France, developed in the sixteenth century and reached its zenith in the eighteenth century. Isabella Bird somehow goes away from this trend by travelling to non-European countries including the Malay Peninsula as in The Golden Chersonese and the Way Thither. Also according to Towner, the Grand Tour produced a number of different forms of literature, each with their own way of communicating the travel experience. These include diaries, letters and journals kept by the tourists during their journey (p. 227). Even though Bird's travels and writings are not for leisure, a major trend during the Grand Tour, her travel writing, or journal on her accounts during her travels are part of the Grand Tour event where writers record their travels and experiences.

In looking at the notion of 'wildness', or its Latin form 'savagery' is a set of culturally self-authenticating devices which includes the ideas of 'madness' and 'heresy' (White, 1972, p. 4). Also according to White, interiorisation of the wilderness and of its traditional occupant, the wild man is similar to the myth of the wild man in ancient cultures (p. 7). This notion might have been innate in a European writer as he or she ventures outside of Europe where more primitive men lived. Although most of the time the difference between the people of the visited land and the Europeans are little. This might be evident in Bird's writing on the Malay Peninsula as well as other countries she has been to.

According to Barry (2002), on the theory of colonialism, children, both black and white, will have been taught to view history, culture and progress as beginning with the arrival of the Europeans (p. 193). There is an importance in reclaiming one's own past in order to begin eroding the colonialist ideology by which that past had been less acknowledged. A major work which inaugurates postcolonial theory is Edward Said's Orientalism written in 1978. According to Said, a specific expose of the Eurocentric universalism which praises what is European or Western while acknowledging the inferiority of what is not. According to Barry, this became a long-standing method of identifying the East as 'Other' and more inferior to the West (p. 193). This notion of Eurocentric could also be seen in Bird's work. Her influence of this notion shall be further discussed in the paper.

\section{Filling the Blank Spaces}

The first approach that can be applied in Isabella Bird's The Golden Chersonese and the Way Thither is by Tim Youngs in his article "Filling the Blank Spaces" (2006). According to the article, blank spaces are voids within us. According to Henry Morton Stanley and Joseph Conrad, there were still blank spaces around the world and travel brings a purpose to fill the blank spaces (Youngs, 2006, p. 1). Once discovered, the places would most probably be exploited for their commercial potential. The colonisers then bring about ideologies of race on the representation of the place and dealings with its inhabitants. This relates to the representation of difference 
International Journal of Applied Linguistics \& English Literature

ISSN 2200-3592 (Print), ISSN 2200-3452 (Online)

Vol. 1 No. 2; July 2012

discussed earlier, where the representation of the culture of the Orient or the 'Other' may be marginalised in the perspective of the west (Bhabha, 1994, p. 2). However, in the context of filling the blank spaces in other parts of the world, this representation of the west contributes to this notion. An example of this can be seen in Letter Seven of the work where Bird (1883) describes how the prescience or foresight of Sir Stamford Raffles marked out Malacca in 1819 as the site for the first free port in the Malayan Seas and was the erected into the capital of the Straits Settlements which includes Malacca and Penang (p. 111). This extract shows that the Malay Peninsula was a blank space yet to be discovered and now became a known port after being discovered and excavated for its natural resources by the colonisers, where in this case are the Europeans. The lines present how the Peninsula is discovered and conquered for its commercial potential (Bird, 1883, p. 111). Bird (1883) describes the voluminous list of the Peninsula's exports which consists of mainly sugar, pepper, tin, nutmegs, mace, sago, tapioca, rice, buffalo hides and horns, rattans, gutta, India rubber, gambir, gums, coffee, dye-stuffs, and tobacco, but the island itself, though its soil looks rich from its redness, only produces pepper and gambir. It is a great entrepot, a gigantic distributing point. Bird also describes how some of the exports are dominated by the Chinese (p. 112). She describes the sale of the monopolies of the preparation and retailing of opium for smoking, and of spirits and other excisable commodities, these monopolies being 'farmed' to private individuals, mostly Chinamen.

Other examples of filling the blank spaces from Bird's The Golden Chersonese and the Way Thither is when she describes the native State being regarded as 'parts unknown' (Bird, 1883, p. 153). According to Bird (1883), the state is regarded as such because the Governor has never visited it and that most would not trust his daughters in a region of tigers, crocodiles, elephants and savages as they are about to venture into the unknown (p. 153).

Bird (1883) also mentions that based on the surveys conducted by Mr. Daly in order to produce the map of the Peninsula shows that there is a vast area on the Malay Peninsula, more than half of it is unexplored (p. 5). These parts unknown are still blank spaces and show a potential for travelling and discovery.

From the introduction, Bird describes how Albuquerque sailed to Aurea Chersonesus, the name it is called by the inhabitants of Malacca. He captured Malacca by sacking it, slaughtering the Moors or the Mohammedans who defended it and destroyed the twenty five thousand houses which kept gold, pearls, spices and other rich exports (Bird, 1883, p. 2). This excerpt shows how the Malay Peninsula is conquered and exploited for its commercial benefits. In the introduction, it also mentions the export of the Peninsula which amounts to $£ 32,353,000$ (Bird, 1883, p. 3). Gold is also a main export of the Peninsula and this too has been conquered by the West (Bird, 1883, p. 5). The Peninsula is truly the golden Chersonese for the Europeans.

Within the same article by Youngs, there is a notion of the relationship between imagination and experience. According to Edward Said in 1985, the ways we imagine places is not a private affair, but are connected through the constructed representations that we possess (Youngs, 2006, p. 2). In other words, travel writing carries preconceptions and is ideological. The author's gender, class, age, nationality, cultural background and education shapes travel writing that they produce. Travel writing is also influenced by the conventions of other literary genres such as the novel and poetry. Travel writing carries a purpose of political, aesthetic and escape and provides a medium for criticising one's own home. However, the travel writing The Golden Chersonese and the Way Thither is a writing describing the culture of the Orient through the European gaze. Therefore, analysing the work takes into consideration the European view that distant territories such as the Malay Peninsula and their native peoples should be subjugated (Said, 1993, p. 10). Despite this limitation, Bird writes in a neutral tone, taking the side of neither the Europeans nor the non-west.

To demonstrate the evidence of this approach in Bird's The Golden Chersonese and the Way Thither is when Bird mentioned that in most of the tropical colonies the ladies exist only in the hope of going 'home'. It is a dreary, aimless life for them - scarcely life, only existence (Bird, 1883, p. 110). Here Bird criticizes the people from her hometown where they only live for the moment in the Malay Peninsula. Bird's background, nationality and cultural beliefs as a European led her to think that life should not be spent by only thinking about the real home, but should be filled with the gaining of knowledge and experience that could only be experienced when going on an adventure, exploring and experiencing a different country than ours.

Another example from the text which demonstrates the relationship between imagination and experience is when she says the ruling race does not show the advantage they have in Letter Seven. The Europeans living in the Malay Peninsula are characterised as pale-skinned man or woman, costumed in the graceless clothes which represents the dim and pale islands in England (Bird, 1883, p. 114). She adds, the English, although recognised as the powerful ruling race is not numerically present in the Peninsula. There are very few English inhabiting the

Page | 166 
International Journal of Applied Linguistics \& English Literature

ISSN 2200-3592 (Print), ISSN 2200-3452 (Online)

Vol. 1 No. 2; July 2012

\section{Peninsula.}

Bird further comments the English when she talks about the Kling women and what they would assume when they see the pale-faced European women who wear highly frilled dresses with poufs, walking painfully in high heels, tight boots, with her figure distorted into the shape of a Japanese sake bottle using the corset. Every movement the English woman makes gave jerks and struggles and for those staying in the Peninsula, would find the type of clothing unsuitable for the climate where it impedes motion, affects health, comfort and beauty (Bird, 1883, p. 117).

Bird (1883) further makes comments on her hometown as she says that only the European part of Singapore which is dull and sleepy looking (p. 117). There is no life or movements around the shops and the merchants hid away in their offices or stay covered under buggies while going about in the streets. Bird (1883) describes their houses as mostly pale, roomy and in the form of detached bungalows, hidden by the beautiful nature of the climate (p. 118). The Europeans are also described as of 'no occupation' who divert themselves with kettle-drums, dances, lawn tennis and various other ways for killing time, all in the temperature of $80^{\circ}$ (Bird, 1883, p. 118).

\section{Ethnography in Travel Writing}

Another approach which can be found in Bird's The Golden Chersonese and the Way Thither is from an article by Joan Pau Rubies, "Ethnography and the Genres of Travel Writing" from the book The Cambridge Companion to Travel Writing edited by Peter Hulme and Tim Youngs. According to Rubies, ethnography is a type of research strategy which enables the researcher to examine and study the cultures and societies that are important parts of the human experience (Hulme and Youngs 244). To demonstrate the importance of ethnography, it is said that educated historian of navigations and conquests paid great attention to their tasks including geographical, economic and the ethnographic summary as part of their work. It can be said as the history of the emergence of a basic analytical categories used in various genres and language. Some of the elements studied under ethnography for travel writing are the political order, kingship, aristocracies, justice and warfare; nationality, economic activities, cities and trade; religion, rituals and festivals; marriage; language and oral rhetoric; dress; technology; and habit of eating and hygiene (Hulme \& Youngs, 2002, p. 251).

The introduction mentions the 'wild zone' to describe the ethnography of the wild tribes of the natives in the Peninsula. She says there is a population of 'Wild Tribes' of eight thousand to eleven thousand people who could still be found in the Peninsula. Bird (1883) wrote on both the dominant culture such as the Europeans living in the Peninsula and the natives of the land (p. 13). These people are the aborigines of the land. Furthermore, description of the aborigines can be seen in the excerpt about the Samangs' appearance. Their hair, compared to the Malays is short and curly but not woolly like that of the Africans. Their complexion are dark brown and nearly black. They live in huts that are easily removable made of leaves and branches (Bird, 1883, p. 15). Orang Benua on the other hand, have hair that are usually matted and curly, but not woolly. They wear clothing that consists of bark cloth waist-cloth. They are often spoken of as 'tree people' (Bird, 1883, p. 16). These are the examples of the ethnography of the natives of the Peninsula.

From the text it can be seen that Bird describes the rich ethnography of the Malay Peninsula including territories such as Singapore, Malacca and Sungei-Ujong. In Letter Seven of the text, Bird describes Singapore as the capital of the Straits Settlements and the place of residence for the governor. Singapore contains a garrison, defensive works, ships of war and a great military and commercial importance. Bird (1883) describes the political status of the state when she says the Governor is assisted by lieutenant-governors at Malacca and Penang and his rule which extends to the three protected States of the Malay Peninsula, which are Sungei-Ujong, Selangor and Perak. The affairs of the states are administered by British Presidents whose duties lie for the Governor (p. 109).

Due to Singapore being such a well-known city, Bird does not go into much detail about it. Bird's notions of Singapore are of its overpowering greenery, an array of colours, the Chinese predominance and its abounding hospitality. She sometimes fails to realise that it is an island due to it being so highly developed (Bird, 1883, p. 109). Bird further describes Singapore as a military station with a vast amount of ships of war which hang about constantly, with a great number of fluctuating societies as well as the numerous officials of the Straits Settlements. In terms of nationality and race, there are the merchant class, English, German, French and American (Bird, 1883, p. 110). She adds, like Victoria Harbour in Hong Kong, Singapore is a free port and the complexities or vexatiousness of a custom-house is unknown (Bird, 1883, p. 111).

Bird also describes the clothing and way of dressing of the people in the Malay Peninsula. She describes that Page | 167 
International Journal of Applied Linguistics \& English Literature

ISSN 2200-3592 (Print), ISSN 2200-3452 (Online)

Vol. 1 No. 2; July 2012

every Oriental costume are worn in the streets. A variety of costumes of different cultures were worn in the Peninsula. The people wore robes of satin, silk, brocade and white muslin. The Parsees wore spotless white garments, the Jews and Arabs in dark and rich silks. The Klings wore Turkey red and white clothes. Bombay merchants wore great white turbans, full trousers and draperies, all white, with crimson silk girdles. Malays wore red sarongs, while the Sikhs in pure white Madras muslin with a classic arrangement for their draperies. The Chinamen coolie wore blue and brown cotton, while the rich merchants in their frothy silk crepes and rich brocade. These create a fascinating environment, much to the eyes of a European (Bird, 1883, p. 114).

Also in the context of ethnography, Bird describes the populations and race in the Peninsula. There are eighty six thousand Chinese living in the Malay Peninsula at that time. Not only are they numerous, they are also rich and important enough to instil Singapore with the feel of a Chinese town with a foreign settlement. The native Malays who initially populated the island now reach a number of twenty two thousand. They are industrious as boatmen and fishermen and form the main body of the police. The Parsees are known as respectable class of merchants on the island as they are known for in all great trading cities of the East. The Javanese who are numerous make good servants and sailors. The Portuguese immigrants from Malacca became small merchants and clerks. Other races that reside on the island are the Bengalees, Jews and Arabs. According to Bird, there are twelve thousand natives of India who reside on the island at that time. The Klings from the Coromandel Coast, compared to all the mingled foreign nationalities are the most attractive in appearance (Bird, 1883, p. 115).

Bird further describes the people of the Peninsula. She mentioned that the Klings from the Coromandel Coast are active and industrious, but they lack the quick-sightedness for opportunities like the Chinese. This trait made the Chinese the most successful of all emigrants (Bird, 1883, p. 115). Bird also states the clothing or dress of the Klings of the Coromandel Coast where their clothing or drapery is a mystery. The drapery covers perfectly but has no sign of tailoring and accentuates the graceful movement of the women. The drapery consists of ten wide yards of soft white muslin or soft red material and ingeniously draped over the bust and lower limbs and forms a girdle at the same time. A shoulder and arm are left bare and the petticoat is short which shows finely turned ankles, high insteps and small feet (Bird, 1883, p. 117). The movements of the Kling woman is described as graceful as she glides along the pavement, her statuesque figure showing a graceful ease. She carries a dark pitcher on her head, touched by a finely moulded arm. Bird (1883) says that the Kling women are beautiful, with a classical form, exquisite in her movements and is artistic in colouring (p. 117). In a way, Bird romanticises her description of the Kling women living in the Malay Peninsula.

Bird's description of the Chinese of the Peninsula is also somewhat romanticised. The Chinese are defined by Bird to be graceful, gliding, stealthy, and have unreadable expressions. They have dark, liquid eyes, full of the Asian mystery (Bird, 1883, p. 118). In Letter Eight, Bird (1883) describes the upper-class Indians in the peninsula with the mark of the Brahmins, a mark of caste which is set conspicuously on their foreheads (p. 122).

The Chinese who travelled with Bird on her sail trip to Malacca are detailed as wearing their pigtails coiled round their heads, while wearing loose cotton trousers (Bird, 1883, p. 123). Bird, at one point thought of Malacca as a Chinese city as the Dutch has not left much trace of their existence in the state. The Portuguese were poor and without much influence. The English too, except in the administrative matters and the government, also left no impact on their existence (Bird, 1883, p. 132). The Chinese have great wealth in diamonds, pearls, sapphires, rubies and emeralds. Their love for Malacca made them proud of beautifying it. They shaped their surroundings like those in Canton, which Bird herself has been to, in the earlier chapter of the writing (Bird, 1883, p. 133). The Chinese have also brought to Malacca gambling and opium-smoking. About one-seventh of the quantity of opium is exported from India to China and is intercepted and consumed in the Straits Settlements. This causes the Malacca government to make a large profit from it. Another description on the ethnography of Malacca is the prohibition of slavery in the state. Slaves from the neighbouring State fly for freedom to the shelter of the British flag (Bird, 1883, p. 134).

Further in the chapters, Bird details the Malays of the Peninsula. To her, they lead odd and less interesting lives. The men only fish and hunt and possess rice land for ploughing rice. Some even say the Malays are quiet, temperate, jealous, suspicious, treacherous and bigoted or opinionated. The women are small and tidy in their work. They weave mats and baskets from reed and palm-leaves. They wear clothing made of cotton or silk from the ankles reaching to the throat. The men in their homes wear the sarong, tied with and ingenious knot. They are not savages and have a complete civilisation of their own and their legal system is derived from the Koran (Bird, 1883 , p. 138). The children of the forest kampongs are very pretty and do not put on much clothing. The dwellings are picturesque and those of the richer Malays are beautiful. All of their ornaments are carefully selected as not to include motifs based on anything regarding heaven or earth. They keep delicately carved Page | 168 
International Journal of Applied Linguistics \& English Literature

ISSN 2200-3592 (Print), ISSN 2200-3452 (Online)

Vol. 1 No. 2; July 2012

arabesques and verses of the Koran. They are all decorative (Bird, 1883, p. 139). Bird gives a description of the Malays according to her views when she travels to the Peninsula. Captain Shaw's description of the Malays is told by Bird. He likes the Malays and sees that they are chaste, gentle, honest and hospitable. If they tell lies, their honour is so tainted that only blood can erase some of the insults from it (Bird 139).

Letter Ten describes the air and festivity of the Chinese New Year celebrated in Malacca. Bird describes the streets trailing with fire and smoke as crackers, squibs and rockets of immense numbers went off incessantly. Gongs, drums and tom-toms were beaten, giving a universal scene of the old city. At one o' clock in the morning, every house in the state is decorated and illuminated as the Chinese men began to make their New Year's call and the celebration starts at six (Bird, 1883, p. 144). Bird then describes the wealth of the Chinese in the state where she saw a child who wore amazing jewelleries and garments during Chinese New Year. The child wore seven necklaces of precious diamonds and stones (Bird, 1883, p. 145). The value of the jewelleries worn by the child is estimated at $\$ 40,000$. All carried by a frail human of only four feet high (Bird, 1883, p. 146).

\section{Conclusion}

In conclusion, Isabella Bird's The Golden Chersonese and the Way Thither contain various approaches to Travel Writing. The two main approaches that are present in the work are ideas on space and travel and ethnography and travel writing. She writes in a neutral tone on her travel accounts to various countries such as Canton, Hong Kong, Singapore and Malacca with emphasis on the Malay Peninsula. Bird also romanticises descriptions of the nature, culture, people and festivities of the Peninsula.

Bird describes how the Malay Peninsula was discovered and its landscape and beauty through her own views. This adheres to the notion of filling the blank spaces from around the world. In terms of the ethnography, Bird describes in detail and in a neutral tone, without describing the people of the peninsula in a biased perspective. Therefore, the travel writing has in a way, contributed in providing a reference into some of the cultures in the Malay Peninsula in the 1880s. It has filled a blank space to the otherwise invisible world of the Golden Peninsula during its time.

\section{References}

Bhabha, H. (1994). The Location of Culture. London: Routledge.

Barry, P. (2002). Beginning Theory: An Introduction to Literary and Cultural Theory. USA: Manchester University Press.

Bird, I. (1883). The Golden Chersonese and the Way Thither. Edinburgh: R. \& R. Clark.

Crossley, N. (2005). Key Concepts in Critical Social Theory. Wiltshire: Sage Publications Ltd.

Hulme, P. \& Youngs, T. (Eds.). (2002). The Cambridge Companion to Travel Writing. Cambridge: Cambridge University Press.

Robinson, M. \& Andersen, H. (2002). Reading Between the Lines: Literature and the Creation of Touristic Spaces. In M. Robinson \& H. Andersen (Eds.), Literature and Tourism: Essays in the Reading and Writing of Tourism (pp. 1-39). Cornwall: Thomson.

Robinson, M. (2002). Between and Beyond the Pages: Literature-Tourism Relationships. In M. Robinson \& H. Andersen (Eds.), Literature and Tourism: Essays in the Reading and Writing of Tourism (pp. 39-80). Cornwall: Thomson.

Said, E. (1993). Culture and Imperialism. London: Chatto and Windus Ltd.

Towner, J. (2002). Literature, Tourism and the Grand Tour. In M. Robinson \& H. Andersen (Eds.), Literature and Tourism: Essays in the Reading and Writing of Tourism (pp. 39-80). Cornwall: Thomson.

White, H. (1972). The Forms of Wildness: Archaeology of an Idea. In E. Dudley \& M. Novak (Eds.), The Wild Man Within: An Image of Western Thought from the Renaissance to Romanticism. (pp. 3-39). London: University of Pittsburgh Press.

Youngs, T. (Ed.). (2006). Travel Writing in the Nineteenth Century: Filling the Blank Spaces. London: Anthem Press. 